\title{
Accounting Based Return Analysis of Selected Fuel and Power Sector Companies in Bangladesh
}

\author{
Shamem Ara Mili ${ }^{*}$, Md. Abdus Sabur ${ }^{2}$, Md. Nazrul Islam ${ }^{3}$ \\ ${ }^{1}$ Assistant Professor, Department of Accounting and Information Systems, Comilla University, Comilla, BANGLADESH \\ ${ }^{2}$ Professor, Department of Accounting and Information Systems, Islamic University, Kushtia, BANGLADESH \\ ${ }^{3}$ Associate Professor, Department of Accounting and Information Systems, Comilla University, Comilla, BANGLADESH \\ *E-mail for correspondence: miliais@yahoo.com
}

No Conflict of Interest: Declared

\begin{abstract}
The present study is an attempt to explore the contemporary profitability status of 5 (five) selected fuel and power sector companies enlisted in DSE, Bangladesh and the interrelationship between sales based returns (GPM, OPM, and NPM) and investment based returns (ROA and ROE) over the period of 2012 to 2016 for the same companies. Using descriptive statistics the present study has found that the profitability position of the sample companies is satisfactory, multiple correlation analysis revealed that there is a positive association between sales based returns and ROA whereas negative association between sales based returns and ROE, and the multiple regression analysis showed that 97.70 percent variance is explained by the predictors OPM, ROA, and ROE of the dependent variable OABR (overall accounting based return) in the selected fuel and power sector companies of Bangladesh.
\end{abstract}

Keywords: Accounting Based Return, Fuel and Power Sector Companies, Growth Rate, Multiple Correlation Analysis, Multiple Regression Analysis

\section{INTRODUCTION}

Electricity and natural gas are the two key sources of power to put in motion in the economic activities of Bangladesh. About $77.90 \%$ populations enjoy the electricity facility in Bangladesh. Gas supplies fulfill $56.00 \%$ of domestic energy demand, and Bangladesh is the $7^{\text {th }}$ largest producer of natural gas among the Asian countries (Wikipedia, 2017). Profitability implies the ability to make profit from all the business activities of an organization (Bose \& Muthueswaran, 2015). Too few researches are performed by the academicians and scholars regarding profitability analysis of fuel and power sector companies in Bangladesh. Even not a single detail research is found to the point of view; whether there is an interrelationship exists between the sales based returns and investment based returns in the fuel and power sector companies of Bangladesh. Now it is a burning question for the corporate management to identify whether additional sales or investment in assets or investment in equity which one is the best option for further improvement of profitability in the corporate sectors. We have tried to answer these queries through applying descriptive statistics, multiple correlation analysis and multiple regression analysis on five years' financial data (2012-2016) of 5 selected fuel and power sector companies enlisted in DSE, Bangladesh.

\section{ReView of ReLATEd Studies}

Venkatesan \& Nagarajan (2012) performed an empirical study of profitability analysis of 5 (five) selected steel companies in India. They calculated gross profit ratio, net profit ratio, operating profit ratio, operating expenses ratio and operating ratio from the data of secondary sources such as the official website of NSE and selected steel companies' financial reports. Using descriptive statistics, $\mathrm{t}$ test and ANOVA they concluded that profitability depends upon the efficient utilization of resources, cutoff expenses, quality of management function in the products, customer services, manpower, goodwill and market share. Dey et al. (2013) conducted a comparative study regarding the profitability of Square and Beximco pharmaceuticals of Bangladesh for a four year period from 2008 to 2011. They applied descriptive statistics on the profitability ratios of the selected pharmaceuticals and found that the overall profitability position of Square pharma is satisfactory as compare to Beximco pharma except for gross profit ratio and operating profit ratio. Tulsian (2014) researched on profitability analysis of Steel Authority of India Ltd. 
(public sector unit) and Tata Steel (private sector unit) for the period of 2007-08 to 2011-12. Using ratio analysis, descriptive statistics and t-test on the secondary data the researcher observed that net income figure alone is not sufficient to measure the efficiency and performance of the business firm unless it is related to some other relevant figures like as sales amount, cost of goods sold, operating expenses, invested capital, etc. Kumar et al. (2015) performed profitability analysis on 5 (five) selected cement companies which are enlisted in Indian stock exchange over the period of 2005 to 2014. Descriptive statistics were used on the selected financial ratios and found that the profitability status of Ambuja cements is better than that of remaining four selected cement companies. Noor \& Jahir (2015) conducted a research on quantifying profitability using financial ratio analysis on the pharmaceutical industry of Bangladesh. They took eight pharmaceuticals as a sample and the study period was ten years (from 2004 to 2013). Applying descriptive statistics and multiple regression analysis on the selected financial ratios the study found that to produce more income for the selected pharmaceuticals, management should utilize their asset more efficiently and effectively.

\section{OBJectives OF THE STUdy}

The objectives of the present study are as follows:

- to make an overview of the profitability status of the selected fuel and power sector companies over the study period

- to examine the interrelationship between sales based returns and investment based returns in the sample companies during the study period

- to find out the extent of the relationship of the selected accounting based returns with overall accounting based return of the sample companies for the study period

\section{Methodology OF The Study}

We took 5 (five) fuel and power sector companies as the sample for our study out of 18 (eighteen) enlisted fuel and power sector companies in Dhaka Stock Exchange Ltd. of Bangladesh (Dhaka Stock Exchange Ltd., 2017). The basic sources of our secondary data were the published annual reports of the sample companies over the period of 2012 to 2016. The statistical methods used for the study are descriptive statistics, multiple correlation analysis, and multiple regression analysis. Selected accounting based returns are used as the financial variables to conduct statistical analysis of our study. Here gross profit margin, operating profit margin and net profit margin are used as sales based accounting returns, and return on assets and return on equity are used as investment based accounting returns. The sample companies, study period and financial variables are selected on the basis of the purposive sampling technique. Acronyms used in the study are BPL for Baraka Power Ltd., GBBPL for GBB Power Ltd., KPCL for Khulna Power Company Ltd., MPL for Meghna Petroleum Ltd., and TGTDCL for Titas Gas Transmission and Distribution Company Ltd.

\section{Hypotheses OF THE STUdY}

The study is based on the following hypotheses:

$\mathrm{H}_{0}$ : There are no significant associations between the sales based returns and investment based returns of the sample companies during the study period.

$\mathrm{H}_{1}$ : There are significant associations between the sales based returns and investment based returns of the sample companies during the study period.

\section{Analysis and Findings of the STUdy}

Table 1: Descriptive Statistical Analysis of Accounting Based Returns of the Selected Companies

\begin{tabular}{|c|c|c|c|c|c|c|}
\hline \multicolumn{2}{|c|}{ Company Name } & BPL & GBBPL & KPCL & MPL & TGTDCL \\
\hline GPM & Mean & 54.70 & 41.83 & 15.21 & 1.16 & 14.02 \\
\cline { 2 - 7 } & CV (\%) & 3.85 & 14.06 & 68.97 & 36.69 & 28.39 \\
\cline { 2 - 7 }$(\%)$ & Growth Rate & 2.21 & -7.63 & 44.14 & -17.59 & -20.52 \\
\hline \multirow{4}{*}{ OPM } & Mean & 46.83 & 22.39 & 16.87 & 0.57 & 9.60 \\
\cline { 2 - 7 }$(\%)$ & CV (\%) & 8.09 & 32.31 & 36.51 & 50.45 & 36.21 \\
\cline { 2 - 7 } & Growth Rate & 4.51 & -8.56 & 20.36 & -30.50 & -28.97 \\
\hline \multirow{4}{*}{ NPM } & Mean & 31.51 & 23.80 & 15.01 & 1.57 & 10.99 \\
\cline { 2 - 7 }$(\%)$ & CV (\%) & 15.28 & 28.00 & 36.06 & 24.47 & 24.60 \\
\cline { 2 - 7 } & Growth Rate & 9.08 & -10.03 & 22.63 & -13.49 & -16.68 \\
\hline \multirow{3}{*}{ ROA } & Mean & 7.73 & 5.97 & 14.61 & 4.20 & 10.77 \\
\cline { 2 - 7 }$(\%)$ & CV (\%) & 15.38 & 27.92 & 53.94 & 21.14 & 26.23 \\
\cline { 2 - 7 } & Growth Rate & 8.90 & -13.14 & 29.99 & -12.04 & -18.56 \\
\hline ROE & Mean & 9.64 & 6.74 & 24.83 & 35.41 & 19.81 \\
\cline { 2 - 7 } & CV (\%) & 12.25 & 34.21 & 40.16 & 29.56 & 29.91 \\
\cline { 2 - 7 }$(\%)$ & Growth Rate & 4.87 & -19.34 & 18.83 & -18.81 & -20.49 \\
\hline
\end{tabular}

Source: Annual Reports (2012-2016) of the Selected Companies

From the Table 1, we can see that the average GPM, OPM, and NPM of BPL is the highest among the sample companies followed by GBBPL, KPCL, TGTDCL, and MPL respectively. CV of GPM, OPM, and NPM of all the sample companies is very high except BPL. On the other hand, the mean ROA of KPCL is the highest among the sample companies followed by TGTDCL, BPL, GBBPL, and MPL respectively. In the case of ROE, MPL showed the highest average return followed by KPCL, TGTDCL, BPL, and GBBPL in order. CV of ROA and ROE of all the sample companies is high. Overall all the sample companies are in a satisfactory level of profitability position. On the basis of sales based returns, BPL shows the best profitability position whereas on the basis of investment based returns, KPCL and MPL shows better profitability position among the selected companies. The growth rate of all the selected accounting based returns for the sample companies is negative except KPCL and BPL. 
Table 2: Pearsonian Correlation Analysis of Accounting Based Returns of the Selected Companies

\begin{tabular}{|c|c|c|c|c|c|c|}
\hline & OABR & GPM & OPM & NPM & ROA & ROE \\
\hline OABR & 1 & $0.814^{* *}$ & $0.874^{* *}$ & $0.908^{* *}$ & $0.589^{* *}$ & $-0.404^{*}$ \\
\hline GPM & $0.814^{* *}$ & 1 & $0.925^{* *}$ & $0.948^{* *}$ & 0.040 & $-0.692^{* *}$ \\
\hline OPM & $0.874^{* *}$ & $0.925^{* *}$ & 1 & $0.954^{* *}$ & 0.170 & $-0.565^{* *}$ \\
\hline NPM & $0.908^{* *}$ & $0.948^{* *}$ & $0.954^{* *}$ & 1 & 0.225 & $-0.627^{* *}$ \\
\hline ROA & $0.589^{* *}$ & 0.040 & 0.170 & 0.225 & 1 & 0.290 \\
\hline ROE & $-0.404^{*}$ & $-0.692^{* *}$ & $-0.565^{* *}$ & $-0.627^{* *}$ & 0.290 & 1 \\
\hline
\end{tabular}

$\mathrm{N}=25,{ }^{* *}$ Correlation is significant at the 0.01 level,

*Correlation is significant at the 0.05 level for 2-tailed test

Source: Annual Reports (2012-2016) of the Selected Companies

Table No. 2 indicates the coefficient of correlation of variable overall accounting based return (OABR) (geometric mean of all the selected returns over the study period) with each of the variables GPM, OPM, NPM, ROA and ROE by the amount of $0.814^{* *}, 0.874^{* *}, 0.908^{* *}, 0.589^{* *}$, and $-0.404^{*}$ respectively. Except for ROE, all the relationships are found to be positive and statistically significant at 1 percent level. The strength of the relationships is shown large scale except ROE. The variable ROE has the small scale of significant negative association with OABR. The investment based return ROA is positively associated with sales based returns GPM, OPM, and NPM whereas another investment based return ROE is negatively associated with sales based returns GPM, OPM, and NPM.

Table 3: Model of the Study and Regression Coefficients Analysis

\begin{tabular}{|c|c|c|c|c|}
\hline Model & R & R Square & Adjusted R Square & Std. Error of the Estimate \\
\hline 1 & 0.988 & 0.977 & 0.974 & 1.25 \\
\hline
\end{tabular}

Source: Annual Reports (2012-2016) of the Selected Companies

The Table No. 3 shows the model summary of performance-oriented variables where Multiple R, R Square, Adjusted R Square and Std. Error of the Estimate are found to be $0.988,0.977,0.974$ and 1.25 respectively. The value of $\mathrm{R}$ square is 0.977 indicating 97.70 percent variance is explained by the predictors OPM, ROA, and ROE of the dependent variable OABR included in the model. Due to high level of multicollinearity (VIF>10) the independent variables GPM and NPM have been kept outside the model.

Table 4: Regression analysis of active variables

\begin{tabular}{|c|c|c|c|c|c|c|c|c|}
\hline \multirow{3}{*}{\multicolumn{2}{|c|}{ Model }} & \multicolumn{3}{|c|}{ UnstandardizedStandardized } & \multirow{3}{*}{$t$} & \multirow{3}{*}{ Sig. } & \multirow{2}{*}{\multicolumn{2}{|c|}{$\begin{array}{c}\text { Collinearity } \\
\text { Statistics }\end{array}$}} \\
\hline & & \multicolumn{2}{|c|}{ Coefficients } & \multirow{2}{*}{\begin{tabular}{|c|c|} 
Coefficients \\
Beta
\end{tabular}} & & & & \\
\hline & & B & Ftd. Error & & & & Tolerance & VIF \\
\hline & Constant & 2.918 & 0.791 & & 3.687 & 0.001 & & \\
\hline & OPM & 0.326 & 0.021 & 0.696 & 15.747 & 0.000 & 0.559 & 1.788 \\
\hline & ROA & 0.776 & 0.057 & 0.517 & 13.558 & 0.000 & 0.752 & 1.329 \\
\hline & ROE & -0.100 & 0.028 & -0.160 & -3.526 & 0.002 & 0.528 & 1.896 \\
\hline
\end{tabular}

Dependent Variable: OABR

Source: Annual Reports (2012-2016) of the Selected Companies
Table No. 4 shows the regression analysis of active variables regarding performance where the constant (intercept) is statistically significant at 1 percent level. From the analysis, it is observed that under the standardized coefficients, the highest contribution to the dependent variable is made by OPM (0.696) with statistically significant at 0.000 level. The coefficient of ROA (0.517) is found significant at 0.000 percent level and ROE (-0.160) with 0.002 percent level. The regression coefficient of each of the predictors is statistically significant and has a positive impact on the dependent variable except ROE. The variance inflationary factor for each of the variables is in the reasonable extent $(\mathrm{VIF}<5)$ indicating the multicollinearity statistics belongs to the acceptable position for the model.

\section{CONCLUSION}

From our analysis and findings it can be concluded that the accounting based returns of the selected companies are satisfactory, but there is a scope to improve the growth of the selected returns for GBBPL, MPL, and TGTDCL. The study also found an association between the sales based returns and investment based returns (insignificant positive in the case of ROA and significant negative in the case of ROE) of the sample companies over the study period. So the management authority of the sample companies should make a balance between investment and level of sales for the further improvement of their accounting based returns because investors provide their attention not only on margin on sales but also on their invested capital to make decisions. The overall accounting based return is significantly depending upon the OPM, ROA, and ROE of the sample companies over the study period. Thus our study will be helpful to the management and stakeholders of the selected fuel and power sector companies to make further investment decisions.

\section{REFERENCES}

Bose, S. C. \& Muthueswaran, S. (2015). Trends and Factors Affecting the Profitability of Selected Public Limited Textile Mills - A Study in Coimbatore District. Shanlax International Journal of Management, Vol. 2, No. 4, April, pp. 6-16.

Dey, M., Dey, S. \& Biswas, S. K. (2013). Comparison of Profitability of Listed Pharmaceutical Companies of Bangladesh. Journal of Commerce \& Accounting Research, Vol. 2, No. 2, April, pp. 33-38.

Dhaka Stock Exchange Ltd. (2011). Sector wise Company List: Dhaka Stock Exchange Ltd. Retrieved June 15, 2017, from Dhaka Stock Exchange Ltd. Website: http://www.dsebd.org/by_industrylisting1.php

Kumar, M. S. M., Pasha, S. M. \& Prakash, T. N. B. (2015). Profitability Analysis of Selected Cement Companies in India. International Journal of Multidisciplinary Research and Modern Education (IJMRME), Vol. 1, Issue 2, pp. 95-99.

Noor, M. F. \& Jahir, R. B. (2015). Quantifying Profitability through Financial Ratio Analysis: Bangladeshi Pharmaceuticals Industry. Australian Journal of Accounting, Economics and Finance, Vol. 1, No. 1, October, pp. 41-55. 
Tulsian, M. (2014). Profitability Analysis (A Comparative Study of SAIL \& TATA Steel). IOSR Journal of Economics and Finance (IOSR-JEF), Vol. 3, Issue 2, Ver. I (Mar. - Apr. 2014), pp. 19-22.

Venkatesan, T. \& Nagarajan, S. K. (2012). An Empirical Study of Profitability Analysis of Selected Steel Companies in India. International Journal of Marketing, Financial Services $\mathcal{E}$ Management Research, Vol. 1, Issue 10, October, pp. 84-100.

Wikipedia. (2017, July 17). U.S. Energy Information Administration (EIA). Retrieved July 25, 2017, from Wikipedia Website: https://en.wikipedia.org/wiki/Natural_gas_and_petroleu m_in_Bangladesh\#cite_note-autogenerated3-1
Wikipedia. (2017, June 8). Key Statistics. Bangladesh Power Development Board. Retrieved June 15, 2017, from Wikipedia Website: https://en.wikipedia.org/wiki/Electricity_sector_in_Bangl adesh\#cite_note-2

Wikipedia. (2017, June 8). Source of Light in Bangladesh: 2015. Retrieved June 15, 2017, from Wikipedia Website: https:/ /en.wikipedia.org/wiki/Electricity_sector_in_Bangl adesh\#cite_note-3

$$
--0--
$$

How to Cite: Mili, S., Sabur, M., \& Islam, M. (2019). Accounting Based Return Analysis of Selected Fuel and Power Sector Companies in Bangladesh. American Journal of Trade and Policy, 6(2), 67-70.

\section{SOCIAL SCIENCE RESEARCH NETWORK 2171 Monroe Avenue, Suite 203, Rochester, NY 14618, USA http://www.ssrn.com/en/} SSRN Link: http://www.ssrn.com/link/American-Journal-Trade-Policy.html 